\title{
D.M. 同調システムの簡易設計法 A SIMPLE DESIGN METHOD FOR TUNED DYNAMIC MASS SYSTEMS
}

\author{
石丸辰治*, 三上淳治**, 秦一平***, 古橋 剛**** \\ Shinji ISHIMARU, Junji MIKAMI, Ippei HATA \\ and Takeshi FURUHASHI
}

\begin{abstract}
This paper introduces a simple design method for tuned dynamic mass(D.M.) systems with very large added mass ratio which is the value of D.M.(rotating inertial mass) to mass of the main structure. The method is constructed on the bases of rule of geometric mean and rule of difference/sum for the natural periods computed under the particular conditions of viscous damping factors of $h_{d}=0$ and $h_{d}=\infty$. The rules are derived from the properties of the invariant point theory. The paper shows that the structures can be designed by the proposed method, which hold viscous damping factors more than 0.2 for the $1^{\text {st }}$ and $2^{\text {nd }}$ modes.
\end{abstract}

Keywords: Invariant point theory, Dynamic mass, Rule of geometric mean for natural periods, Rule of difference/sum for natural periods 定点理論, ダイナミック・マス，固有周期の「相乗平均」則，固有周期の「差分和」則

\section{1. はじめに}

本論はダイナミック・マス（D.M.:回転慣性要素）を利用した構造 システムの設計法を論じたものである。すなわち、「質量の制御」も 利用した簡易な制震設計法を提案している論文である。

振動制御に質量項を利用するという考え方は機械振動制御の分野 において早くから取り入れられており、その理論の基礎は TMD と して整理されている。基礎理論となっているのは Den Hartog の定点 理論である ${ }^{12)}$ ことはよく知られている。

この理論を基礎に機械分野ではいろいろな研究が行なわれている が、建築の分野でも搭状構造物や高層構造物の風摇れの制御を目的 としたパッシブ制振機構として応用されてきている。しかし、主振 動系としての質量が大きく、大きな制振効果を上げるためには大き な付加質量が要求されるところから、アクティブ機構を利用しても 地震時の応答制御を有効に行うには困難な状況にある。

こうした理由から、大地震にも対応できるように、付加質量を何 らかの形で増幅しようとする試みがなされてきた。その初期の代表

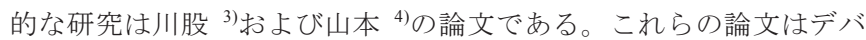
イスとして大きな質量増幅を図り、振動方程式の質量項を調整しよ うとしたものである。

これにヒントを得て石丸 ${ }^{5)}$ は梃子を利用して付加質量を制御する
構造システムを提案し、高次モードが全く刺激されない「モード制 御」が可能であることを示した。しかし質量の増幅に関しては梃子 倍率 $\beta$ がせいぜい $2 \sim 3$ 倍程度であり、実際設計を展開するには困難 であった。

こうしたことから、構造物の質量を分割して 2 つのシステムを構 成し、相互に連成させることで大きな減衰を得るための試みが成さ れた。

その一つが石丸の BMD(Building Mass Damper) システム ${ }^{677)}$ であ り、他の代表的な研究は背戸・䔖山 ${ }^{89910) 111}$ の連結制振システムであ る。いずれも定点理論が基本であるが、興味深いのは葲山らの連結 制振の研究で、最適調整が周期のみの関係式で表されると示唆して いることである。

一方、デバイスの開発では、ボールねじにより軸方向運動を回転

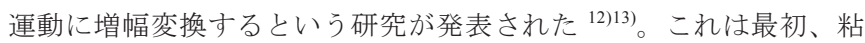
性ダンパーとして開発されたものであるが、梃子倍率 $\beta$ を 20 40 倍 にすることが可能であり、振動現象が生ずると、付加質量 $m_{d}$ は $m_{d} \beta^{2}$ に増幅される ${ }^{14) 17)}$ 。これにより、本格的に振動方程式の質量 項、粘性項、剛性項を互いに連動させる調整法の研究が始まった。

その本格的研究の最初の論文が石丸・古橋によるモード制御の研

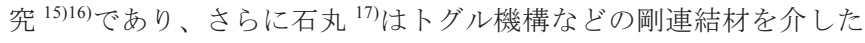

\footnotetext{
* (株) i2S2 技術顧問 . 工博

** 日本大学理工学部大学院理工学研究科

$* * *$ 日本大学理工学部建築学科 助教 ·博士 (工学)

**** 日本大学理工学部建築学科 准教授・博士 (工学)
}

Technological Advisor, i2S2 Co., Ltd., Dr. Eng.

Graduate School of Science and Technology, Nihon University

Assistant Prof., College of Science and Technology, Nihon University, Dr. Eng.

Assoc. Prof., College of Science and Technology, Nihon University, Dr. Eng. 
システムの数值解析を行い、少ないデバイスで粘性減衰定数 $20 \%$ 程 度の効率を上げることは可能であることを紹介している。なお、同 書では $m_{d} \beta^{2}$ が振動現象が生じることによって生成されるところか らこれを「ダイナミック・マス(D.M.)」と呼称している。

一方、「同調粘性マスダンパー」という考え方を具体化する斉藤賢 二らの研究がある 18)1920)。これは定点理論を基本に回転慣性要素之 柔支持材を直列連結することにより同調マス・ダンパー・システム を構成したもので、多くの最適同調理論式を誘導している。そこで は最適同調になるマス比や粘性減衰定数を陽な表式として提案して いる。

しかし、実際設計では運用の簡便さが求められることから、本論 文は、単純な固有值解析を介した設計法を提案したものである。す なわち、第 2 章では 1 質点系に対して、定点理論の同調式を工学的 推論から固有周期の「相乗平均」則という形で構成する方法を誘導、 第 3 章ではこれを 2 質点系に拡張、第 4 章ではこの「相乗平均」則が 多自由度系としてのせん断型多質点系及び複雑な曲げフレーム系で も直接的に適用できることを示したものである。

\section{2. 固有周期による同調式}

いま、図 1 の 1 質点系にD.M.とばねの直列連結した系を考える。 このシステムの振動方程式は次のようになる。

$$
\begin{aligned}
& \left\{\begin{array}{c}
\ddot{x}_{d} \\
\ddot{x}
\end{array}\right\}+\left[\begin{array}{cc}
2 h_{d} \omega_{d} & -2 h_{d} \omega_{d} \\
0 & 0
\end{array}\right]\left\{\begin{array}{c}
\dot{x}_{d} \\
\dot{x}
\end{array}\right\} \\
& +\left[\begin{array}{cc}
\omega_{0}{ }^{2} \kappa_{k}\left(1+\frac{1}{\eta_{d}}\right) & \omega_{0}{ }^{2} \\
\omega_{0}{ }^{2} \kappa_{k} & \omega_{0}{ }^{2}
\end{array}\right]\left\{\begin{array}{c}
x_{d} \\
x
\end{array}\right\}=-\left\{\begin{array}{l}
1 \\
1
\end{array}\right\} \ddot{y} \\
& \eta_{d}=\frac{m^{\prime}}{m}, \kappa_{k}=\frac{k_{d}}{k}, \omega_{0}{ }^{2}=\frac{k}{m}, \omega_{d}{ }^{2}=\frac{k_{d}}{m^{\prime}}=\kappa_{k} \frac{\omega_{0}^{2}}{\eta_{d}}, \\
& \frac{k_{d}}{m}=\frac{k_{d}}{k} \cdot \frac{k}{m}=\omega_{0}{ }^{2} \kappa_{k}, \\
& \frac{c_{d}}{m}=\frac{c_{d}}{m^{\prime}} \cdot \frac{m^{\prime}}{m}=2 h_{d} \omega_{d} \eta_{d}, \frac{c_{d}}{m^{\prime}}=2 h_{d} \omega_{d}
\end{aligned}
$$

ただし、(2)式のような表記を導入している。個々の係数の意味は説 明の必要がないだろう。

さて、 $h_{d}=\infty$ の時、 $m^{\prime}=0, x=x_{d}$ であるから(1)の第 2 式は次のよ うになる。

$$
\begin{aligned}
& \ddot{x}+\omega_{0}{ }^{2}\left(1+\kappa_{k}\right) x=-\ddot{y} \\
& \therefore \omega_{\infty}{ }^{2}=\frac{k+k_{d}}{m}=\omega_{0}{ }^{2}+\omega_{0}{ }^{2} \kappa_{k} \rightarrow\left(\frac{\omega_{\infty}}{\omega_{0}}\right)^{2}=1+\kappa_{k}
\end{aligned}
$$

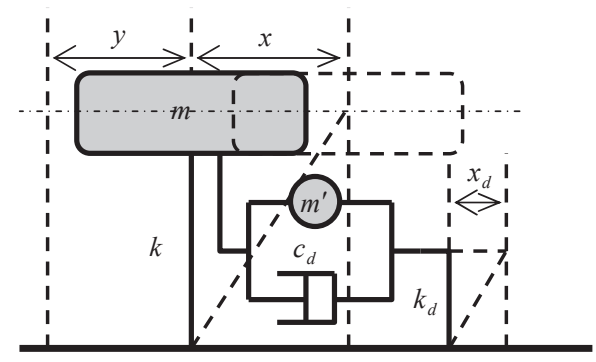

図 1 1 質点系のD.M.同調システム
また、 $h_{d}=0$ の時の特性方程式は次のようになる。

$$
\left(\frac{\omega}{\omega_{0}}\right)^{4}-\left(1+\kappa_{k}+\frac{\kappa_{k}}{\eta_{d}}\right)\left(\frac{\omega}{\omega_{0}}\right)^{2}+\frac{\kappa_{k}}{\eta_{d}}=0
$$

上式の 2 つの固有值を $\omega_{0,1}{ }^{2}, \omega_{0,2}{ }^{2}$ として表し、 $\omega_{0,1}=2 \pi / T_{0,1}, \omega_{0,2}=2 \pi / T_{0,2}, \omega_{\infty}=2 \pi / T_{\infty}$ とおけば、相互の関係は下 図のようになる。

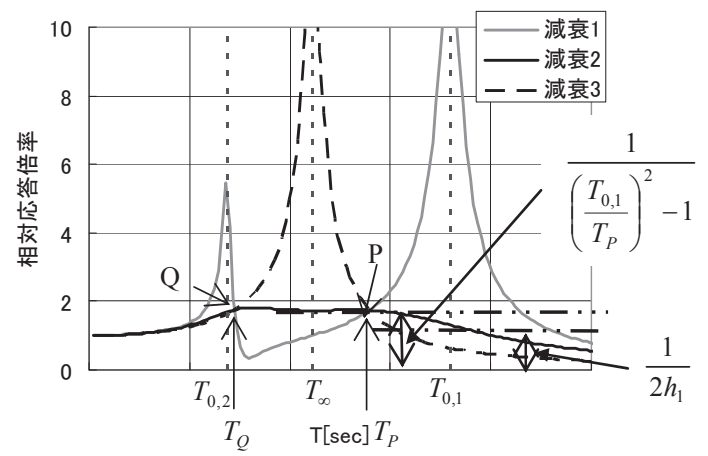

図 2 定点理論における周期の関係

定点理論は、図 2 のように $h_{d}=\infty$ （減衰 3）と $h_{d}=0$ （減衰 1） の共振曲線図の交点である $\mathrm{P}$ 及び $\mathrm{Q}$ の振幅值が減衰係数を変化(減 衰 2)させても一定值として存在しており、また両者の值が同一にな るとき最適調整されているという原理である。

ここではこの原理を工学的視点から次のように利用している。 $h_{d}=0$ の時の応答倍率の図は基本的には減衰ゼロの応答倍率図を 固有周期 $T_{0,1}$ と $T_{0,2}$ を中心に 2 つ描いたものであり、また $h_{d}=\infty$ の 図は、固有周期を $T_{\infty}$ とする減衰ゼ口の応答倍率図と解釈する。厳密 には各モードの刺激関数值に影響されるが、ここでは 1 次、 2 次の 值はほぼ同值の部位に対して解析していると解釈できる（補足説明 参照)。したがって、P点の振幅值は次のようになる。

$$
\frac{1}{\left(\frac{T_{0,1}}{T_{P}}\right)^{2}-1}=\frac{1}{1-\left(\frac{T_{\infty}}{T_{P}}\right)^{2}}
$$

前者は周期 $T_{0,1}$ を中心とした減衰ゼロの周期 $T_{P}$ の応答倍率であ り、後者は周期 $T_{\infty}$ を中心にした減衰ゼロの周期 $T_{P}$ の応答倍率であ る。定点理論によりこれらは等しいとして等值したのが上式の意味 である。周期 $T_{0,2}$ にも同様の展開をすれば、次式が誘導される。

$$
T_{P}=\sqrt{\frac{T_{0,1}{ }^{2}+T_{\infty}{ }^{2}}{2}}, T_{Q}=\sqrt{\frac{T_{\infty}{ }^{2}+T_{0,2}{ }^{2}}{2}}
$$

最適同調は $\mathrm{P}$ 点と $\mathrm{Q}$ 点の振幅が等しいときに生じるので、次式が 成立する筈である。

$\frac{1}{1-\left(\frac{T_{\infty}}{T_{P}}\right)^{2}}=\frac{1}{\left(\frac{T_{\infty}}{T_{Q}}\right)^{2}-1}$

上式に(7)式の関係を代入すると次式を得る。

$$
\sqrt{T_{0,1} \cdot T_{0,2}}=T_{\infty}
$$


円振動数に対して書き直せば次のようになる。

$$
\sqrt{\omega_{0,1} \cdot \omega_{0,2}}=\omega_{\infty} \text { or } \frac{1}{2}\left(\log {\omega_{0,1}}^{2}+\log \omega_{0,2}{ }^{2}\right)=\omega_{\infty}{ }^{2}
$$

これらは、 $h_{d}=\infty$ と $h_{d}=0$ の系の各固有周期 (或は固有円振動数) の間に「相乗平均」則ともいえる関係が成立する時が最適同調であ ることを示している。

さて、これより図 1 のシステムの最適同調式を誘導する。いうま でもなく(5)式の左辺の第 3 項は 2 次方程式の根の性質から次式が成 立する。

$$
\left(\frac{\omega_{0,1}}{\omega_{0}}\right)^{2}\left(\frac{\omega_{0,2}}{\omega_{0}}\right)^{2}=\frac{\kappa_{k}}{\eta_{d}}
$$

これより、(11)式と(4)式の関係を(10)式に代入すれば次式が得られ る。

$$
\begin{aligned}
& \frac{\kappa_{k}}{\eta_{d}}=\left(1+\kappa_{k}\right)^{2} \rightarrow \kappa_{k}^{2}-\frac{1-2 \eta_{d}}{\eta_{d}} \kappa_{k}+1=0 \rightarrow \\
& \kappa_{k}=\frac{1-2 \eta_{d} \pm \sqrt{1-4 \eta_{d}}}{2 \eta_{d}}
\end{aligned}
$$

これは定点の振幅から誘導した式 ${ }^{18)}$ と同じである。このことは、 間接的に(9)式の誘導法が正しいことを示唆している。

次に最適粘性減衰定数の関係を考察しょう。減衰ゼロの時の周期 $T_{P}$ の振幅は(6)式によって与えられている。減衰をどのように付与 しても、これ以下の応答倍率を得ることができないというのが定点 理論の主張しているところである。そこで、この応答倍率を最大值 として調整する固有周期 $T_{0,1}$ の粘性減衰定数 $h_{1}$ の設定を工学的な観 点から次のように考える。図 2 に示すように周期 $T_{0,1}$ の最大応答倍 率は $1 / 2 h_{1}$ であるが、(6)式左辺の周期 $T_{P}$ の振幅は、その何倍に相当 するかという形で整理する。すなわち、 $\alpha / 2 h_{1}$ として $\alpha$ の值を仮定、 (6)式左辺の值に等值させ、最適同調するときの、 $\alpha$ の值を試行錯誤 的に求めるのである。その結果 $\alpha=1.6$ として次式を誘導している。

$$
h_{1} \approx 0.8 \frac{T_{0,1}{ }^{2}-T_{\infty}^{2}}{{T_{0,1}{ }^{2}+T_{\infty}{ }^{2}}^{2}}
$$

同様にして、2 次モードの最適粘性減衰定数 $h_{2}$ は

$$
h_{2} \approx 0.8 \frac{T_{\infty}^{2}-T_{0,2}{ }^{2}}{T_{\infty}^{2}+T_{0,2}{ }^{2}}
$$

この両者の粘性減衰定数がほぼ一致する場合が最適減衰になって いる。なぜならば、最適同調周期の(9)式を(13)、(14)式に代入すれ ば同一の值になるからである。この特性は固有周期（或は固有円振 動数) の自乗值の差と和で構成されるから「差分和」則とでも名付 けることができよう。

図 3 は $\eta_{d}=0.25, \kappa_{k}=1.0, m=1.0$ ton,$k=100 \mathrm{kN} / \mathrm{m}$ として計算した ものである。これによる固有值計算は $T_{0,1}=0.719(s), T_{0,2}=0.275(s)$, $T_{\infty}=0.444(s)$ であり、これを(13),(14) 式に代入すると $h_{1}=h_{2} \approx 0.358$ となる。固有值計算で $c_{d}=5.0 \mathrm{kN} \cdot \mathrm{s} / \mathrm{m}$ を代入すると $h_{1}=h_{2} \approx 0.358$ が得られる。図 3 の減衰 2 がそれであり、ほぼ最適 減衰を与えていることが分かる。

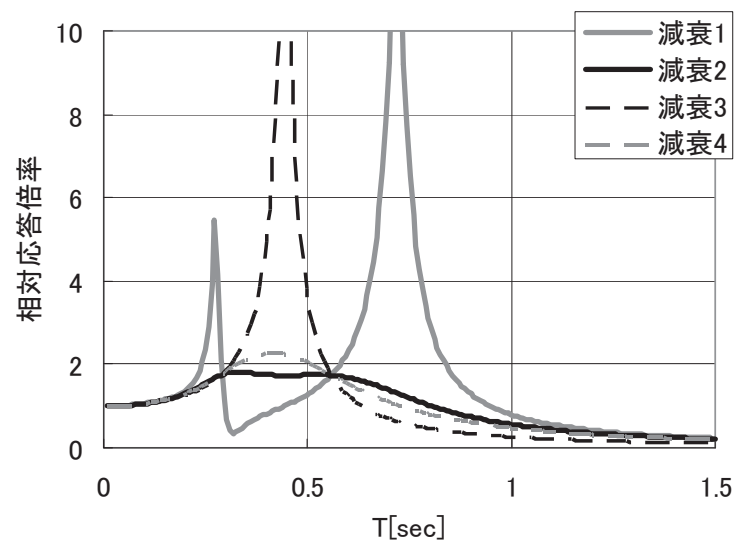

$m=1.0$ ton,$m^{\prime}=0.25$ ton,$k=k_{d}=100 \mathrm{kN} / \mathrm{m}$ 減衰1: $c_{d}=0.5 \mathrm{kN} \cdot \mathrm{s} / \mathrm{m}$, 減衰 $2: c_{d}=5.0 \mathrm{kN} \cdot \mathrm{s} / \mathrm{m}$ 減衰3: $c_{d}=40.0 \mathrm{kN} \cdot \mathrm{s} / \mathrm{m}$, 減衰 $4: c_{d}=7.0 \mathrm{kN} \cdot \mathrm{s} / \mathrm{m}$

図 31 質点系の共振曲線

\section{2 質点系の同調式}

次に図 4 の 2 質点系の下部構造のみにD.M.システムを装着した場 合の同調について考察する。

これは多質点系の上部を 1 質点、下部を 1 質点として模擬したもの である。多質点系への拡張については後述する。

振動方程式は次のようになる。

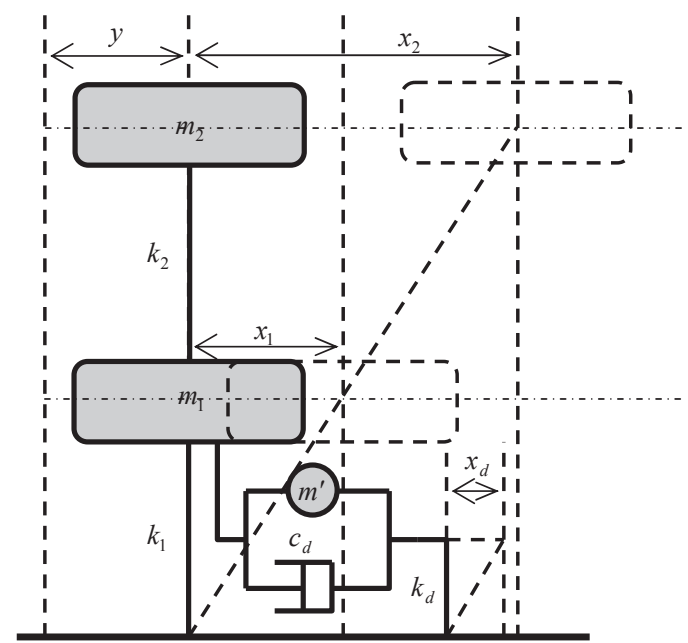

図 4 2 質点系の数学モデル

$\left\{\begin{array}{l}\ddot{x}_{2} \\ \ddot{x}_{1} \\ \ddot{x}_{d}\end{array}\right\}+\left[\begin{array}{ccc}0 & 0 & 0 \\ 0 & 0 & 0 \\ 0 & -2 h_{d} \omega_{d} & 2 h_{d} \omega_{d}\end{array}\right]\left\{\begin{array}{l}\dot{x}_{2} \\ \dot{x}_{1} \\ \dot{x}_{d}\end{array}\right\}$

$+\left[\begin{array}{ccc}\omega_{s, 2}{ }^{2} & -\omega_{s, 2}{ }^{2} & 0 \\ -\omega_{s, 2}{ }^{2} \frac{1}{\gamma_{m}} & \omega_{s, 2}{ }^{2} \frac{1}{\gamma_{m}}+\omega_{s, 1}{ }^{2} & \omega_{d}{ }^{2} \frac{\eta_{m}}{\gamma_{m}} \\ -\omega_{s, 2}{ }^{2} \frac{1}{\gamma_{m}} & \omega_{s, 2}{ }^{2} \frac{1}{\gamma_{m}}+\omega_{s, 1}{ }^{2} & \omega_{d}{ }^{2} \frac{\eta_{m}}{\gamma_{m}}+\omega_{d}{ }^{2}\end{array}\right]\left\{\begin{array}{l}x_{2} \\ x_{1} \\ x_{d}\end{array}\right\}=-\left\{\begin{array}{l}1 \\ 1 \\ 1\end{array}\right\} \ddot{y}$ 
ただし、次のような表記を採用している。

$\eta_{m}=\frac{m^{\prime}}{m_{2}}, \omega_{s, 2}^{2}=\frac{k_{2}}{m_{2}}, \omega_{s, 1}^{2}=\frac{k_{1}}{m_{1}}, \omega_{d}^{2}=\frac{k_{d}}{m^{\prime}}, \tau_{k}=\frac{k_{d}}{k_{2}}, \quad \gamma_{m}=\frac{m_{1}}{m_{2}}$,

$\frac{c_{d}}{m^{\prime}}=2 h_{d} \omega_{d}, \frac{k_{2}}{m_{1}}=\frac{k_{2}}{m_{2}} \cdot \frac{m_{2}}{m_{1}}=\omega_{s, 2}^{2} \frac{1}{\gamma_{m}}, \frac{k_{d}}{m_{1}}=\frac{k_{d}}{m^{\prime}} \cdot \frac{m^{\prime}}{m_{2}} \cdot \frac{m_{2}}{m_{1}}=\omega_{d}^{2} \cdot \frac{\eta_{m}}{\gamma_{m}}$

$\frac{\omega_{d}^{2}}{\omega_{s, 2}^{2}}=\frac{\frac{k_{d}}{k_{2}} \cdot \frac{k_{2}}{m_{2}} \cdot \frac{m_{2}}{m^{\prime}}}{\frac{k_{2}}{m_{2}}}=\frac{k_{d}}{k_{2}} \cdot \frac{m_{2}}{m^{\prime}}=\frac{\tau_{k}}{\eta_{m}}$

$\omega_{s, 2}$ は上部構造単独の円振動数、 $\omega_{s, 1}$ は下部構造単独の固有円振動 数、 $\eta_{m}$ は上部構造質量に対する D.M.の質量比、 $\tau_{k}$ は上部ばね剛性 に対する D.M.連結ばねの剛性比である。

$h_{d}=\infty$ の時 $\rightarrow x_{1}=x_{d}$ であり、その特性方程式は

$\left(\frac{\omega}{\omega_{s, 2}}\right)^{2}=\lambda^{2}$ とおけば、次のようになる。

$\lambda^{4}-A \lambda^{2}+B=0$

各係数は次のとおりである。

$$
\begin{aligned}
& A=\left\{1+\frac{1}{\gamma_{m}}+\left(\frac{\omega_{s, 1}}{\omega_{s, 2}}\right)^{2}+\frac{\tau_{k}}{\gamma_{m}}\right\} \\
& =1+\frac{1}{\gamma_{m}}+B=C+B \\
& B=\left(\frac{\omega_{s, 1}}{\omega_{s, 2}}\right)^{2}+\frac{\tau_{k}}{\gamma_{m}} \\
& C=1+\frac{1}{\gamma_{m}}
\end{aligned}
$$

故に $h_{d}=\infty$ の時の固有值 $\lambda_{\infty, 1}, \lambda_{\infty, 2}$ は

$$
\begin{aligned}
& \lambda_{\infty, 1}{ }^{2}=\left(\frac{\omega}{\omega_{s, 2}}\right)_{\infty, 1}^{2}=\frac{1}{2} A-\frac{1}{2} \sqrt{A^{2}-4 B} \\
& \lambda_{\infty, 2}{ }^{2}=\left(\frac{\omega}{\omega_{s, 2}}\right)_{\infty, 2}^{2}=\frac{1}{2} A+\frac{1}{2} \sqrt{A^{2}-4 B}
\end{aligned}
$$

一方、 $h_{d}=0$ の時の特性方程式は同様に次のようになる。

$$
\lambda^{6}-a_{1} \lambda^{4}+a_{2} \lambda^{2}-a_{3}=0
$$

各係数は(21)式のとおりである。

$$
\begin{aligned}
& a_{1}=\left\{1+\frac{1}{\gamma_{m}}+\left(\frac{\omega_{s, 1}}{\omega_{s, 2}}\right)^{2}+\frac{\tau_{k}}{\eta_{m}}\left(1+\frac{\eta_{m}}{\gamma_{m}}\right)\right\}=A+\frac{\tau_{k}}{\eta_{m}}=C+B+\frac{\tau_{k}}{\eta_{m}} \\
& a_{2}=\left\{1+\frac{1}{\gamma_{m}}+\left(\frac{\omega_{s, 1}}{\omega_{s, 2}}\right)^{2}\right\} \frac{\tau_{k}}{\eta_{m}}+\frac{\tau_{k}}{\gamma_{m}}+\left(\frac{\omega_{s, 1}}{\omega_{s, 2}}\right)^{2}=\left\{C+\left(\frac{\omega_{s, 1}}{\omega_{s, 2}}\right)^{2}\right\} \frac{\tau_{k}}{\eta_{m}}+B \\
& a_{3}=\left(\frac{\omega_{s, 1}}{\omega_{s, 2}}\right)^{2} \frac{\tau_{k}}{\eta_{m}}
\end{aligned}
$$

いま、上式が因数分解できたとすれば次式が成立しなければならな い。

$$
\begin{aligned}
& \left(\lambda^{4}-\delta_{1} \lambda^{2}+\delta_{2}\right)\left(\lambda^{2}-\delta_{3}\right)=\lambda^{6}-\left(\delta_{1}+\delta_{3}\right) \lambda^{4}+\left(\delta_{1} \delta_{3}+\delta_{2}\right) \lambda^{2}-\delta_{2} \delta_{3} \\
& =\lambda^{6}-a_{1} \lambda^{4}+a_{2} \lambda^{2}-a_{3}=0
\end{aligned}
$$

したがって次の関係が成立する。 $\delta_{1}+\delta_{3}=a_{1}$

$\delta_{1} \delta_{3}+\delta_{2}=a_{2}$

$\delta_{2} \delta_{3}=a_{3}$

(16) また

$$
\lambda^{4}-\delta_{1} \lambda^{2}+\delta_{2}=0
$$

の固有值は次のとおりである。

$$
\lambda_{0,1}^{2} 、 \lambda_{0,2}^{2}=\frac{1}{2} \delta_{1} \pm \frac{1}{2} \sqrt{\delta_{1}^{2}-4 \delta_{2}}
$$

これらの各固有值の関係は図 5 に示寸とおりである。

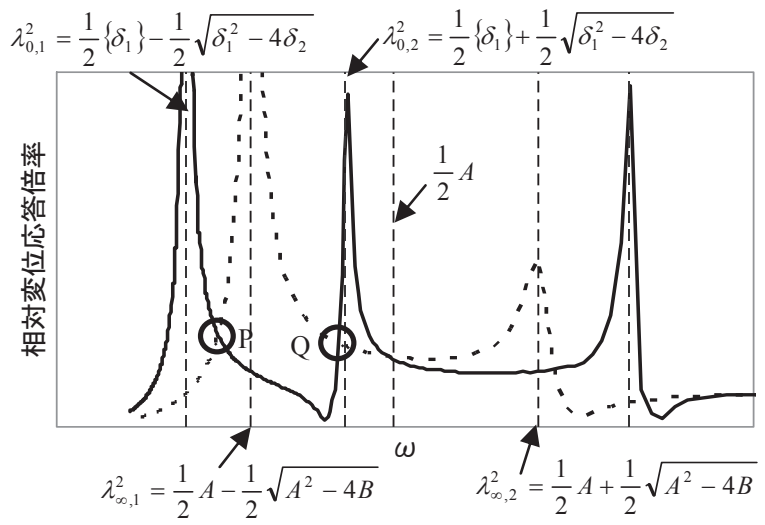

図 5 各固有值の相対的な関係

なお、ここでは下記の条件が成立するものとして解析を進めるもの とする。

$$
\lambda_{\infty, 2}^{2} \geq \lambda_{0,2}^{2}
$$

いま最適同調として(10)式の考え方を採用すれば、次のように表さ れる。

$\lambda_{0,1}^{2} \cdot \lambda_{0,2}^{2}=\lambda_{\infty, 1}^{4}$

これに(19),(25)式を代入すれば次式を得る。

$$
\delta_{2}=\left(\frac{1}{2} A-\frac{1}{2} \sqrt{A^{2}-4 B}\right)^{2} \rightarrow \delta_{2}=\lambda_{\infty, 1}^{4}=\frac{1}{2} A\left(A-\sqrt{A^{2}-4 B}\right)-B
$$

上式と(23)式の第 1 及び第 2 式より次式が成立する。

$$
\begin{aligned}
& \delta_{1}=a_{1}-\delta_{3} \\
& \delta_{3}^{2}-a_{1} \delta_{3}+a_{2}-\lambda_{\infty, 1}^{4}=0
\end{aligned}
$$

したがって

$$
\delta_{3}=\frac{a_{1}}{2} \pm \sqrt{\left(\frac{a_{1}}{2}\right)^{2}+\lambda_{\infty, 1}^{4}-a_{2}}, \quad \delta_{1}=\frac{a_{1}}{2} \mp \sqrt{\left(\frac{a_{1}}{2}\right)^{2}+\lambda_{\infty, 1}^{4}-a_{2}}
$$

一方、(23)式の第 3 式より $\delta_{3}=a_{3} / \delta_{2}$ であるから、これに(28)式を代 入すれば次式を得る。

$$
\begin{aligned}
& \delta_{3}=\frac{a_{1}}{2} \pm \sqrt{\left(\frac{a_{1}}{2}\right)^{2}+\lambda_{\infty, 1}^{4}-a_{2}}=\frac{a_{3}}{\lambda_{\infty, 1}^{4}} \\
& \rightarrow\left(\frac{a_{3}}{\lambda_{\infty}^{4}}\right)^{2}+a_{2}=\lambda_{\infty, 1}^{4}+\frac{a_{1} a_{3}}{\lambda_{\infty, 1}^{4}}
\end{aligned}
$$

この式に(18),(21)式の各係数の表式を代入して整理すれば $\left(\tau_{k} / \eta_{m}\right)$ に関する次の 2 次方程式となる。 


$$
\begin{aligned}
& \left\{\left(\frac{\left(\frac{\omega_{s, 1}}{\omega_{s, 2}}\right)^{2}}{\lambda_{\infty, 1}^{4}}\right)^{2}-\frac{\left(\frac{\omega_{s, 1}}{\omega_{s, 2}}\right)^{2}}{\lambda_{\infty, 1}^{4}}\right\}\left(\frac{\tau_{k}}{\eta_{m}}\right)^{2} \\
& +\left\{C\left\{1-\frac{\left(\frac{\omega_{s, 1}}{\omega_{s, 2}}\right)^{2}}{\lambda_{\infty, 1}^{4}}\right\}+\left(\frac{\omega_{s, 1}}{\omega_{s, 2}}\right)^{2}\left\{1-\frac{B}{\lambda_{\infty, 1}^{4}}\right\}\right\}\left(\frac{\tau_{k}}{\eta_{m}}\right)+B-\lambda_{\infty, 1}^{4}=0
\end{aligned}
$$

これより次のような設計手順が考えられる。

1) $\gamma_{m},\left(\frac{\omega_{s, 1}}{\omega_{s, 2}}\right)^{2}$ の系を設定する。

2)連結ばねの剛性 $\tau_{k}$ を仮定する

3) $h_{d}=\infty$ の時の固有值 $\lambda_{\infty, 1}, \lambda_{\infty, 2}$ が(19)式により求められる。 したがって(28)式より $\delta_{2}$ も求められる。

4) (32)式の係数が既知となるので $2 つ の ~\left(\frac{\tau_{k}}{\eta_{m}}\right)$ を得る。

5) (20)式の 2 組の係数 $a_{1}, a_{2}, a_{3}$ が知れる。

6) (30)式により、2 組の $\delta_{3}, \delta_{1}$ が知れる。

7) $\delta_{3}, \delta_{1}$ の 2 組の係数に $\delta_{2} \delta_{3}=a_{3}$ の関係が成立していれば解で あるが、成立しなければ充却することになる。また、少なく とも $\delta_{3} \geq \lambda_{0,2}{ }^{2}$ を満足していなければならない。 なお、1)2)の組合せが悪ければ解が存在しない場合もある。

8) 以上の手順で最適同調の剛性比と質量比が求められたので、 最適減衰は固有值解析を行い、(13)、(14)式が成立するよう に求めていけばよい。

【例題】をひとつ示しておく。

1) $\gamma_{m}=0.15 、\left(\frac{\omega_{s, 1}}{\omega_{s, 2}}\right)^{2}=3$ の系として設定する。

$$
\frac{k_{1}}{k_{2}}=0.45 \quad \because\left(\frac{\omega_{s, 1}}{\omega_{s, 2}}\right)^{2}=\frac{m_{2}}{m_{1}} \cdot \frac{k_{1}}{k_{2}}=\frac{1}{\gamma_{m}} \cdot \frac{k_{1}}{k_{2}}
$$

2)連結ばねの剛性を $\tau_{k}=0.45$ と仮定する。

$$
\frac{\tau_{k}}{\gamma_{m}}=\frac{0.45}{0.15}=3
$$

すなわち次の系を仮定している。

$$
\begin{aligned}
& \frac{\tau_{k}}{\gamma_{m}}=\frac{m_{2}}{m_{1}} \cdot \frac{k_{d}}{k_{2}}=\frac{m_{2}}{m_{1}} \cdot \frac{k_{1}}{k_{2}} \cdot \frac{k_{d}}{k_{1}} \\
& =\left(\frac{\omega_{s, 1}}{\omega_{s, 2}}\right)^{2} \cdot \frac{k_{d}}{k_{1}} \rightarrow \frac{k_{d}}{k_{1}}=1.0
\end{aligned}
$$

3)この場合の係数は次のようになる。

$$
\begin{aligned}
& A=\left\{1+\frac{1}{\gamma_{m}}+\left(\frac{\omega_{s, 1}}{\omega_{s, 2}}\right)^{2}+\frac{\tau_{k}}{\gamma_{m}}\right\} \\
& =1+6.6666+3+3=13.666 \\
& B=\left(\frac{\omega_{s, 1}}{\omega_{s, 2}}\right)^{2}+\frac{\tau_{k}}{\gamma_{m}}=3+3=6
\end{aligned}
$$

したがって

$$
\left.\begin{array}{l}
\lambda_{\infty, 1}^{2} \\
\lambda_{\infty, 2}^{2}
\end{array}\right\}=\frac{1}{2}\left(13.666 \mp \sqrt{13.666^{2}-4 \cdot 6}\right)=\left\{\begin{array}{l}
0.454 \\
13.213
\end{array}\right.
$$

$$
\delta_{2}=\lambda_{\infty, 1}^{4}=0.2061
$$

4) (32)式より $2 つ の ~\left(\frac{\tau_{k}}{\eta_{m}}\right)$ を求める。

$\therefore\left(\frac{\tau_{k}}{\eta_{m}}\right)=\left\{\begin{array}{l}0.9224 \\ 0.0318\end{array}\right.$

最初の解より

$\eta_{m}=\frac{0.45}{0.9224}=0.488$

第 2 の解より

$$
\eta_{m}=\frac{0.45}{0.0318}=14.15
$$

(例 1-8)の解は大きすぎるので棄却する。

5) (例 1-7)の場合の係数 $a_{1}, a_{2}, a_{3}$ は次のとおりである。

$$
\begin{aligned}
& a_{1}=C+B+\frac{\tau_{k}}{\eta_{m}}=7.666+6+0.9224=14.5891 \\
& a_{2}=\left\{C+\left(\frac{\omega_{s, 1}}{\omega_{s, 2}}\right)^{2}\right\} \frac{\tau_{k}}{\eta_{m}}+B \\
& =(7.6666+3) 0.9224+6=15.834 \\
& a_{3}=\left(\frac{\omega_{s, 1}}{\omega_{s, 2}}\right)^{2} \frac{\tau_{k}}{\eta_{m}}=3 \cdot 0.9224=2.7672 \\
& \delta_{3}=\frac{a_{1}}{2} \pm \sqrt{\left(\frac{a_{1}}{2}\right)^{2}+\lambda_{\infty, 1}^{4}-a_{2}}=\left\{\begin{array}{l}
13.445 \\
1.1443
\end{array}\right.
\end{aligned}
$$

しかし、

$\delta_{3}=\frac{a_{3}}{\delta_{2}}=\frac{2.7672}{0.20612}=13.43$

であるから、 $\delta_{3}=13.43$ を採用する。したがって

$\delta_{1}=\frac{a_{1}}{2}-\sqrt{\left(\frac{a_{1}}{2}\right)^{2}+\lambda_{\infty, 1}^{4}-a_{2}}=1.144$

$\left.\begin{array}{l}\lambda_{0,1}^{2} \\ \lambda_{0,2}^{2}\end{array}\right\}=\frac{1}{2}\left(\delta_{1} \mp \sqrt{\delta_{1}^{2}-4 \delta_{2}}\right)=\left\{\begin{array}{l}0.224 \\ 1.070\end{array}\right.$

したがって

$h_{1}=0.8 \frac{\lambda_{\infty, 1}^{2}-\lambda_{0,1}^{2}}{\lambda_{\infty, 1}^{2}+\lambda_{0,1}^{2}}=0.27$

$h_{2}=0.8 \frac{\lambda_{0,2}^{2}-\lambda_{\infty, 1}^{2}}{\lambda_{\infty, 1}^{2}+\lambda_{0,2}^{2}}=0.27$

となる。

$h_{1}$ と $h_{2}$ の值がほぼ等しいので、最適同調されているといえる。 この解の結果は次節の例題で間接的に検証する。

(例 1-9) 


\section{4. 多自由度系への拡張}

\section{1 せん断型多質点系}

ここでも例題的に説明しておこう。対象とするのは 10 質点系であ るが、最下層 1 層にシステムを装着するものとする。表 1 に 10 質点 の諸元を示す。ただし、最下層は調整層なので、質量のみを記して おく。なお、（）内の値は下記の計算から求められた值を提示して いる。前節の例題の結果を応用して概略、次のように設定する。

$$
\gamma_{m}=0.15,\left(\frac{\omega_{s, 1}}{\omega_{s, 2}}\right)^{2}=3
$$

この設定は、ソフト・ファースト・ストーリーを構成するためで あり、その意図を(例 2-3)の結果と表 1 から読み取っていただきたい。

表 110 質点系の諸元

\begin{tabular}{|l|l|l|l|}
\hline \multirow{2}{*}{ FL. } & 質量 & 減衰係数 & 剛性 \\
\cline { 2 - 4 } & ton & $\mathrm{kN} \cdot \mathrm{s} / \mathrm{m}$ & $\mathrm{kN} / \mathrm{m}$ \\
\hline 10 & 1000.0 & 8000.0 & 800000.0 \\
\hline 9 & 1000.0 & 8000.0 & 800000.0 \\
\hline 8 & 1000.0 & 8000.0 & 800000.0 \\
\hline 7 & 1000.0 & 8000.0 & 800000.0 \\
\hline 6 & 1000.0 & 8500.0 & 850000.0 \\
\hline 5 & 1000.0 & 8500.0 & 850000.0 \\
\hline 4 & 1000.0 & 9000.0 & 900000.0 \\
\hline 3 & 1000.0 & 9000.0 & 900000.0 \\
\hline 2 & 1000.0 & 9000.0 & 900000.0 \\
\hline 1 & 1140.0 & $(815.0)$ & $(81500.0)$ \\
\hline
\end{tabular}

まず、上部 9 質点の系を減衰ゼロとしての固有值計算を行う。得ら れる 1 次モードの固有周期は 1.28 s、有効質量は 7598.7 ton、有効剛 性は $181171.1 \mathrm{kN} / \mathrm{m}$ である。

次にこれを等価な 2 質点系として構成する。

$$
\begin{aligned}
& \gamma_{m}=\frac{m_{1}}{m_{2}}=0.15, \omega_{s, 1}^{2}=3 \omega_{s, 2}^{2}=71.5 \\
& k_{1}=71.5 \cdot m_{1}=81500 \mathrm{kN} / \mathrm{m}
\end{aligned}
$$

となっている。[例題]の結果より $\eta_{m}=0.488, \tau_{k}=0.45$ を採用するとす れば、

$$
\begin{aligned}
& m^{\prime}=\eta_{m} m_{2}=3700 t o n \\
& k_{d}=\tau_{k} k_{2}=81500 \mathrm{kN} / \mathrm{m}
\end{aligned}
$$

これで固有值計算を行うと、

$$
T_{0,1}=2.85 \mathrm{~s}, T_{0,2}=1.32 \mathrm{~s}, T_{\infty, 1}=1.97 \mathrm{~s}
$$

であるが、「相乗平均」則から

$$
\sqrt{T_{0,1} T_{0,2}}=1.94 \mathrm{~s}
$$

となっており、ほぼ最適值になっていることが分かる。

また、「差分和」則から次のように求まる。

$$
\begin{aligned}
& h_{1}=0.8 \frac{T_{0,1}^{2}-T_{\infty, 1}^{2}}{T_{0,1}^{2}+T_{\infty, 1}^{2}}=0.28 \\
& h_{2}=0.8 \frac{T_{\infty, 1}^{2}-T_{0,2}^{2}}{T_{0,2}^{2}+T_{\infty, 1}^{2}}=0.30
\end{aligned}
$$

固有值解析からこれに相当する粘性減衰係数は $15000 \mathrm{kN} \cdot \mathrm{s} / \mathrm{m}$ で ある。各結果は表 2 のとおりである。実際の固有周期はそれぞれ、 $T_{\infty, 1}$ のほうに近づいているのが分かる。ただし、粘性減衰定数は設 計值に一致している。また、図 6 はこの系の共振曲線を示したもの
である。各減衰係数の值は、

減衰 1 が $: c_{d}=500 \mathrm{kN} \cdot \mathrm{s} / \mathrm{m}$

減衰 2 が $: c_{d}=15000 \mathrm{kN} \cdot \mathrm{s} / \mathrm{m}$

減衰 3 が $: c_{d}=80000 \mathrm{kN} \cdot \mathrm{s} / \mathrm{m}$

に設定してある。

(a)が第 10 層、(b)が第 6 層である。最適同調されている様子が分る。

表 2 固有值解析の結果

\begin{tabular}{|c|c|c|}
\hline & 固有周期 & 減衰定数 \\
\hline 1 次 & $2.533 \mathrm{~s}$ & 0.279 \\
\hline 2 次 & $1.489 \mathrm{~s}$ & 0.303 \\
\hline 3 次 & $0.598 \mathrm{~s}$ & 0.010 \\
\hline
\end{tabular}

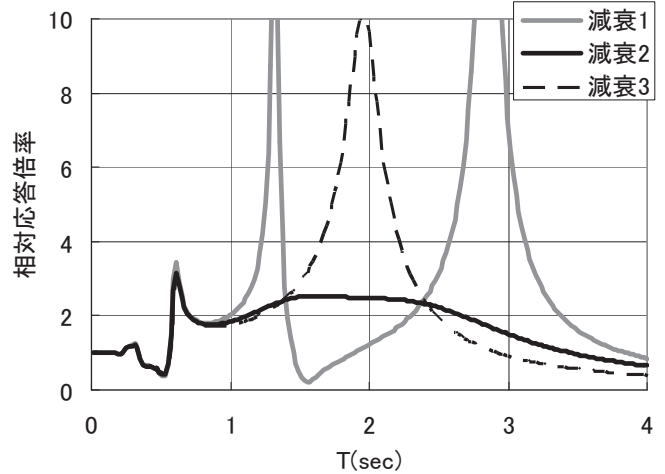

(a) 10 層共振曲線

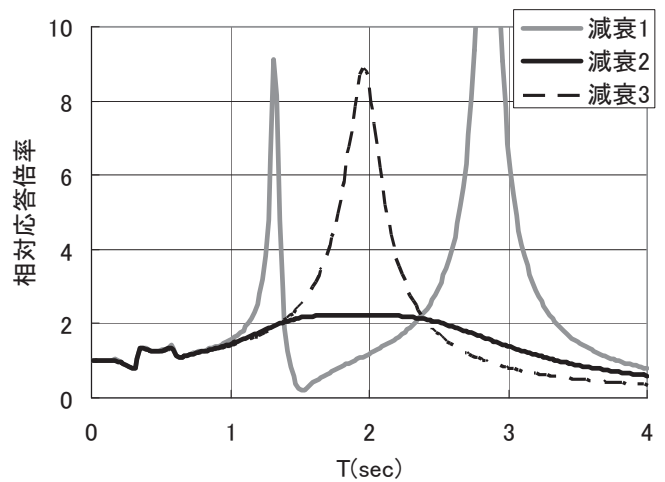

(b) 6 層共振曲線

減衰 $1: c_{d}=500 \mathrm{kN} \cdot \mathrm{s} / \mathrm{m}$, 減衰 $2: c_{d}=15000 \mathrm{kN} \cdot \mathrm{s} / \mathrm{m}$ 減衰 $3: c_{d}=80000 \mathrm{kN} \cdot \mathrm{s} / \mathrm{m}$

図 6 表 1 の系に D.M.同調した時の共振曲線

なお、1 次の減衰定数を若干大きくしたい場合は、 $m^{\prime}$ を少し大きく し、 $T_{0,1}$ を少し長くすればよい。例えば、 $m^{\prime}=3900$ ton として固有值 解析を行えば次の值を得る。

$$
T_{0,1}=2.88 \mathrm{~s}, T_{0,2}=1.35 \mathrm{~s}, T_{\infty, 1}=1.95 \mathrm{~s}
$$

「相乗平均」則から

$$
\sqrt{T_{0,1} T_{0,2}}=1.97 \mathrm{~s}
$$

「差分和」則から

$$
h_{1}=0.8 \frac{T_{0,1}^{2}-T_{\infty, 1}^{2}}{T_{0,1}^{2}+T_{\infty, 1}^{2}}=0.30, \quad h_{2}=0.8 \frac{T_{\infty, 1}^{2}-T_{0,2}^{2}}{T_{0,2}^{2}+T_{\infty, 1}^{2}}=0.28
$$

となる。一般に 


$$
\begin{aligned}
& T_{\infty, 1} \geq \sqrt{T_{0,1} T_{0,2}} \rightarrow h_{2} \geq h_{1} \\
& T_{\infty, 1} \leq \sqrt{T_{0,1} T_{0,2}} \rightarrow h_{2} \leq h_{1}
\end{aligned}
$$

の関係があることに注意すれば、最適同調の微調整の方法が工夫で きよう。

\section{2 曲げ型フレーム系}

次に曲げ変形特性を有する図 7 のフレームを対象とする。フレー ムの詳細は文献 ${ }^{177}$ に示してある。幅 $16 \mathrm{~m}$ 、高さ $44 \mathrm{~m}$ の 11 層 2 スパ ンであり、節点質量は外柱 50ton、内柱 100 ton であり、1 次モード に対して 0.01 の剛性比例型粘性減衰が設定してある。

ここでは、トグル 1 基に装着してある D.M.は次の表 3 に示す 3 つ する。

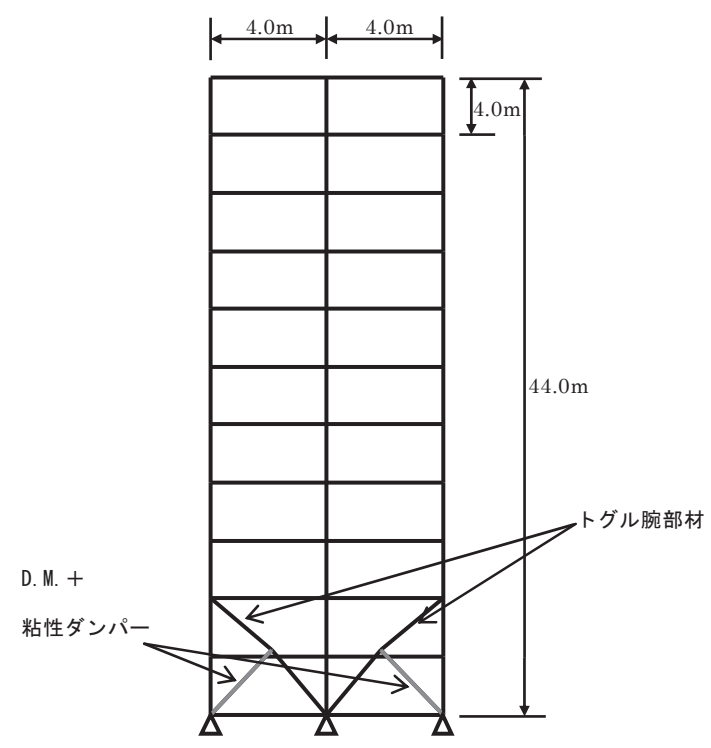

図 7 曲げ型フレーム系

ここでの設計は直接的に展開する。まず、トグルの腕の性能を最 初に設定し、次に最適同調としての D.M.の值を決定していくのであ る。その際に「相乗平均」則を利用することはいうまでもない。表 3 はその結果である。

D.M. $=0$ で $h_{d}=\infty$ の時の固有周期 $T_{\infty}$ と、モデル $1,2,3$ の各 D.M.を 対象に $h_{d}=0$ の時の固有周期 $T_{0,1}, T_{0,2}$ を算出し、その適合度を $\sqrt{T_{0,1} T_{0,2}} / T_{\infty}$ によって判断するのである。表 3 からモデル 2 が最適 であることが分かる。それぞれの粘性減衰定数は「差分和」則から 類推すればよい。その值が小さいと判断されれば、トグル腕の剛性 を高めて、再度調整することになる。

図 8 は粘性減衰係数を $c=600 \mathrm{kN} \cdot \mathrm{s} / \mathrm{m}$ (減衰 2 )に設定したときの共 振曲線を描いたものである。モデル 2 が最適同調になっていること が分かる。ただし、構造部材には 0.01 の剛性比例型の粘性減衰が付 与されているので、定点の位置が微妙にずれているが実際設計では 無視できる值であろう。なお、この比例減衰も加味してモデル 2 の 固有值解析をすると次のようになる。

$$
T_{1}=1.68 \mathrm{~s}, h_{1}=0.21, T_{2}=1.25 \mathrm{~s}, h_{2}=0.23
$$

なお、 1 次の粘性減衰定数を少し大きくしたい時は、(例 2-12)式 にしたがって、D.M.を若干小さくし、 $T_{\infty, 1}$ の周期を短くすればよい。
このように、固有值解析から直接的に同調システムを構成できる のが理解できよう。

表 3 各モデルと最適同調度

\begin{tabular}{|c|c|c|c|}
\hline & モデル 1 & モデル 2 & モデル 3 \\
\hline D.M. & 50 ton & 150 ton & 250 ton \\
\hline$T_{0,1}$ & $1.70 \mathrm{~s}$ & $1.86 \mathrm{~s}$ & $2.09 \mathrm{~s}$ \\
\hline$T_{0,2}$ & $0.81 \mathrm{~s}$ & $1.13 \mathrm{~s}$ & $1.27 \mathrm{~s}$ \\
\hline$\sqrt{T_{0,1} T_{0,2}}$ & $1.17 \mathrm{~s}$ & $1.45 \mathrm{~s}$ & $1.63 \mathrm{~s}$ \\
\hline$T_{\infty}$ & $1.46 \mathrm{~s}$ & $1.46 \mathrm{~s}$ & $1.46 \mathrm{~s}$ \\
\hline$\sqrt{T_{0,1} T_{0,2}} / T_{\infty}$ & 0.80 & 0.99 & 1.12 \\
\hline$h_{1}$ & 0.12 & 0.19 & 0.28 \\
\hline$h_{2}$ & 0.42 & 0.20 & 0.11 \\
\hline
\end{tabular}
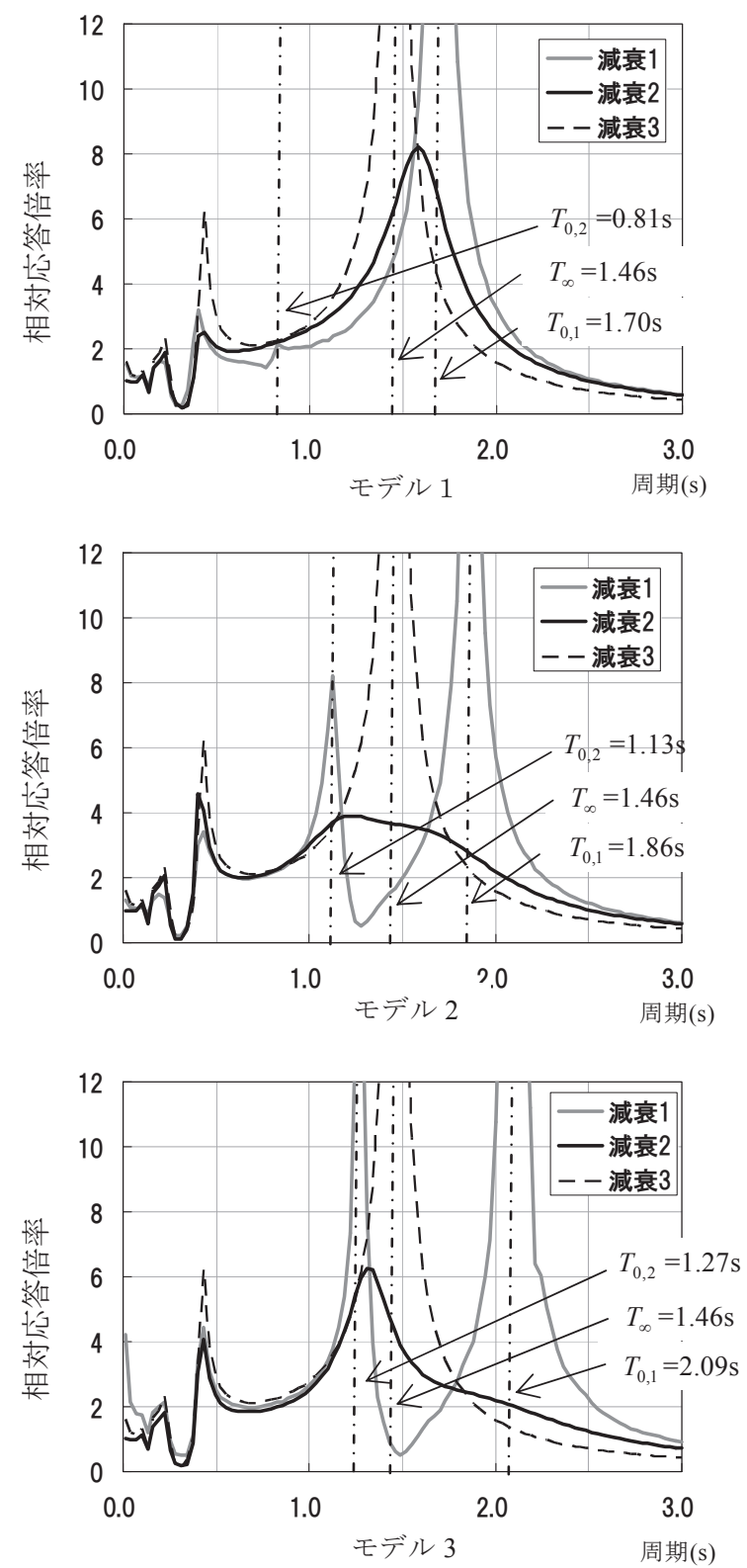

減衰1: $c=0 \mathrm{kN} \cdot \mathrm{s} / \mathrm{m}$, 減衰2: $c=600 \mathrm{kN} \cdot \mathrm{s} / \mathrm{m}$, 減衰3: $c=\infty$

図 8 各モデルによる $h_{d}=0$ と $h_{d}=\infty$ の時の固有周期の変化と 最上層の共振曲線 


\section{5. 結論}

D.M.同調システムの設計が簡単に精度よく進めることを示した が、その成功の要因は次のとおりである。

1) $\quad h_{d}=\infty$ と $h_{d}=0$ の系の各固有周期の表式である「相乗平 均」則が成立することを定点理論の特性から誘導したこと。

2) 最適減衰係数の具体的な值は、複素固有值解析を介して 得られる 1 次, 2 次の粘性減衰定数が $h_{d}=\infty$ と $h_{d}=0$ の系 の各固有周期の「差分和」則により誘導される值に一致す るようにすればよいこと。

3）これらの関係は多質点系にも適用でき、特に 2 質点系で は簡単な代数方程式から最適パラメータを求めるルーチン が構成できたこと。

4）多質点系の最下層に同調システムを装着する場合は、上 部構造の 1 次の有効質量、有効剛性を用いて、3)の 2 質点系 の同調計算ルーチンで求められるパラメータを利用するこ とで可能であること。

5) フレーム系は、せん断系の結果も利用できるが、直接的 に「相乗平均」則と「差分和」則を利用しても可能である こと。

6) 本方法が成立するのは、D.M.の值が容易に調整可能であ り、本格的に「質量制御」が実現できるからである。

なお、「相乗平均」則という同調法は、システムの装着位 置を最下層に限定していない事に注意して欲しい。そうし た例については引き続き発表する予定である。

\section{補足説明}

下図（補図 1 ）は、図 3 のモデルの共振関係図である。(a), (b) は、 $h_{d} \fallingdotseq 0$, $h_{d}=\infty$ に対応寸る共振曲線図である。(c), (d)は、それぞれ $T_{0,1}$ 及び $T_{0,2}$ を 中心とした 1 自由度系の減衰ゼロの共振曲線図である。(e), (f)は、その共振 曲線図に対して D.M.同調システムの主質点部位の 1 次モード及び 2 次モー ドの刺激関数 $\beta_{1} r_{1}, \beta_{2} r_{2}$ を乗じた共振曲線図である。本例の場合、 $\beta_{1} r_{1}=0.724, \beta_{2} r_{2}=0.276$ であるが、図中の線 $\mathrm{QP}$ と線 $\mathrm{Q}^{\prime} \mathrm{P}^{\prime}$ は、ほぼ平 行であり、刺激関数值の值をほぼ同一として扱ってもよい事を示唆している。 また、第 3 章，第 4 章の計算結果からも分かるように、最終的には複素固有 值解析により確認しているので、「相乗平均」則を適用した設計法は実用上支 障ないといえる。

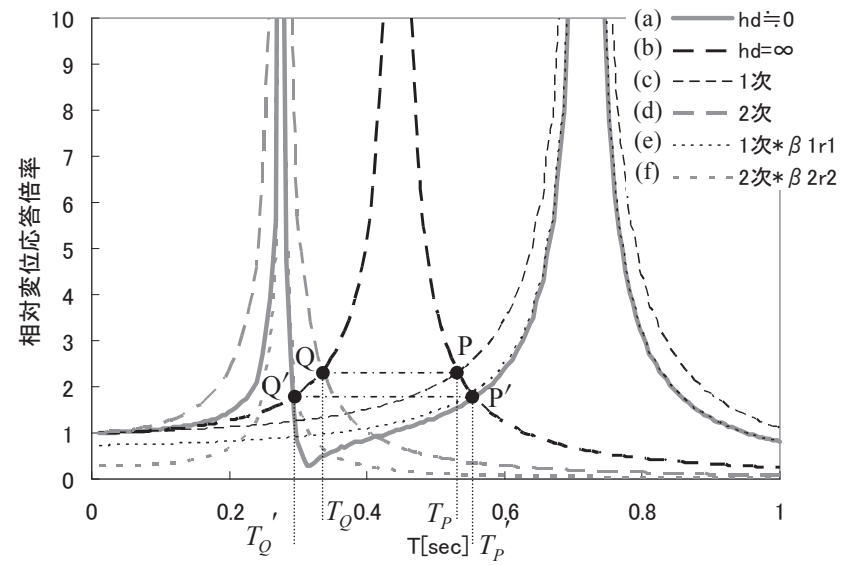

\section{参考文献}

1) J.P.Den Hartog : Mechanical Vibration, 4thed. , McGraw-Hill, pp.87-106, 1956

2）制振工学ハンドブック編集委員会：制振工学ハンドブック，コロナ社, 2008.5

3）川股重也他：制振機構に関する研究（その 1〜 その 3)，日本建築学会大 会学術講演梗概集，pp.857-862， 1973.10

4）山本鎮男他：振り子とてこの作用を応用した球形タンクの免震装置，圧 力技術，Vol.13 No.5, 1975

5）石丸辰治他：地震応答を低減するためのモード制御法，構造工学論文集 Vol.36B, pp.71-84, 1990.3

6）石丸辰治：構造物の地震応答制御概論「応用力学シリーズ 2 ; 建築構造 物の設計力学と制御動力学」, 日本建築学会, pp.199-202, 1994.11

7）石丸辰治：同調多重質量ダンパーによる高層建物の制震，機械力学・計 測制御講演論文集(Vol.B) No.910-39(III-B), 日本機械学会, pp.12-16, 1991.7

8）背戸一登，松本幸人：振動の制御,丸善，1999.3

9）䔖山満, 安井譲, 背戸一登: 連結制振におけるダンパーの最適配置に関 する研究，日本機械学会論文集(C 編)65 巻 630 号, pp.535-543, 1999.2

10）䔖山満，安井譲，背戸一登：連結制振の基本モデルにおける連結バネと ダンパーの最適解の誘導, 日本建築学会構造系論文集 第 529 号, pp.97-104, 2000.3

11）䔖山満，安井譲，背戸一登：多モード連結制振を対象とした連結バネと 最適配置に関寸る研究, 日本建築学会構造系論文集 第 538 号, pp.79-86, 2000.12

12）新垣忠志，黒田英二，有馬文昭，井上豊，馬場研介：ボールねじを用い た制震装置の開発 (その 1 試験概要)，日本建築学会技術報告集 第 8 号, pp.224-239, 1999.6

13）鈴木亨，古橋剛，光坂勇治：増幅機構付き減衰装置の高速度領域におけ る性能評価 (その 1 ) 試験概要, 日本建築学会大会学術講演梗概集.B-2, pp.759-760.2003.9.

14）宮島洋平, 石丸辰治, 秦一平: DMV ダンパーを用いたトグル制震装置 (その 1 DM ダンパーの性能試験)，日本建築学会大会学術講演梗概 集.B-2, pp.835-836，2007.8

15）古橋剛, 石丸辰治：慣性接続要素によるモード分離，日本建築学会構造 系論文集 第 576 号，pp.55-62，2004.2

16）古橋剛，石丸辰治：慣性接続要素による多質点振動系の応答制御，日本 建築学会構造系論文集 第 601 号, pp.83-90, 2006.3

17）石丸辰治：対震設計の方法ーダイナミックデザインへの誘い一，建築技 術, 2008.7

18）斎藤賢二, 栗田哲, 井上範夫 : 慣性接続要素を利用した線形粘性ダンパ 一による一質点構造の最適応答制御と Kelvin モデル化手法に関する考 察，構造工学論文集 Vol.53B，pp.53-66，2007.3

19）斉藤賢二，杉村義文，井上範夫：慣性接続要素を利用した粘性ダンパー による制振構造の応答制御に関する一考察, 構造工学論文集 Vol.54B, pp.623-648, 2008.3

20）油川健樹，堀則男，五十子幸樹，井上範夫：同調粘性マスダンパーの調 和振動応答低減効果に関寸る比較検討, 日本地震工学会大会 2008 梗概 集, pp.116-117，2008.11

(2010年 1 月 8 日原稿受理，2010年 3 月 10 日採用決定）

補図 1 図 3 のモデルの共振曲線図 